\title{
CAPSULE COMMENTARIES \\ Capsule Commentary on Zallman et al., Unauthorized Immigrants Prolong the Life of Medicare's Trust Fund
}

\author{
Leighton $\mathrm{Ku}, \mathrm{PhD}, \mathrm{MPH}$ \\ Department of Health Policy and Management, George Washington University, Washington, DC, USA.
}

J Gen Intern Med 31(1):100

DOI: $10.1007 / \mathrm{s} 11606-015-3440-1$

(C) Society of General Internal Medicine 2015

$\mathrm{U}$ nauthorized immigrants have become the modern day pariahs. They are barred from programs like Medicare, Medicaid, and even the new Health Insurance Marketplace, no matter how long they have lived in the U.S., how sick or how impoverished. Paradoxically, they make payments into Medicare, but are prohibited from eventually receiving Medicare benefits. Part A of Medicare (the hospital component) is financed by workers'-including undocumented workers' - payroll taxes, reserved in the Medicare Trust Fund and paid out as Medicare benefits to elderly or disabled beneficiaries. The government has acknowledged that undocumented immigrants' untapped contributions to the Social Security Trust Fund, the counterpart to the Medicare fund, prolong its solvency and sustain Social Security benefits for retired citizens. ${ }^{1}$

Leah Zallman and her associates have estimated that unauthorized immigrants contributed a net surplus of $\$ 35$ billion to the Medicare Trust Fund, extending its solvency. ${ }^{2}$ They also find that proposals to offer a pathway to citizenship for a portion of the undocumented would continue to create a generous surplus. Even though the new citizens could eventually become eligible for Medicare, legalization would increase their earning power, thereby boosting their tax contributions to the Medicare Trust Fund.

It has long been known that immigrants, including the unauthorized, use medical services sparingly and, contrary to popular misconceptions, even use emergency departments less than citizens, ${ }^{3}$ so tend to be less costly even when they are insured. But ideological barriers have made it almost impossible to overcome the political challenges needed to improve the conditions for the undocumented, whether through legislation or executive action. For now, unauthorized immigrants are likely to remain in the shadows and reliant on the health care safety net.

Conflict of Interest: There is no conflict of interest regarding this commentary.

Corresponding Author: Leighton $\mathrm{Ku}, \mathrm{PhD}, \mathrm{MPH}$; Department of Health Policy and Management, George Washington University, 950 New Hampshire Ave, NW, Washington, DC, 20052 USA (e-mail: lku@gwu.edu).

\section{REFERENCES}

1. Goss S, Wade A, Skirvin P, et al. Effects of unauthorized immigration on the actuarial status of the Social Security Trust Funds. Actuarial Note 151, Office of the Chief Actuary, Social Security Administration, April 2013.

2. Zallman $\mathbf{L}$, Wilson $\mathbf{F}$, Stimpson $\mathbf{J}$, et al. Unauthorized immigrants prolong the life of Medicare's Trust Fund. J Gen Intern Med. 2015. doi:10.1007/ s11606-015-3418-Z.

3. Ku L, Matani S. Left Out: Immigrants' Access to Health Care and Insurance. Health Affairs. 2001;20(1):247-56.

This comment refers to the article available at: $h t t p: / / d x$.doi.org/10.1007/ s11606-015-3418-z.

Published online August 20, 2015 